\title{
Spontaneous and induced metamorphosis in the American brook lamprey, Lampetra appendix
}

\author{
John A. Holmes, Helen Chu, Syeda A. Khanam, Richard G. Manzon, \\ and John H. Youson
}

\begin{abstract}
We described the seven stages of spontaneous metamorphosis in the American brook lamprey (Lampetra appendix) and assessed the importance of size as a determinant of spontaneous and induced metamorphosis. Serum concentrations of the thyroid hormones $(\mathrm{TH})$ thyroxine $\left(\mathrm{T}_{4}\right)$ and triiodothyronine $\left(\mathrm{T}_{3}\right)$ were measured in metamorphosing and nonmetamorphosing L. appendix. The sequence of stages in metamorphosis and changes in the relative lengths of most body regions were consistent with data reported for other lamprey species. However, premetamorphic and metamorphosing L. appendix in the early stages of metamorphosis (1-3) were much larger in size (at least $155 \mathrm{~mm}$ and $5.40 \mathrm{~g}$ ) than has been observed for other lamprey species. Serum concentrations of $\mathrm{T}_{4}$ and $\mathrm{T}_{3}$ were high by the end of the larval period and declined significantly by stage 2 of metamorphosis. Larvae $\geq 130 \mathrm{~mm}$ in length were treated with either potassium perchlorate $\left(\mathrm{KClO}_{4} ; 0.01\right.$ and $\left.0.05 \%\right)$ or $10 \mathrm{mg} / \mathrm{L}$ propylthiouracil (PTU; $0.0001 \%$ ) for 117 days from September to January to determine if metamorphosis could be induced by these goitrogens. Both concentrations of $\mathrm{KClO}_{4}$ successfully induced metamorphosis in L. appendix, but the incidence of metamorphosis (62\%) was much lower than reported in sea lampreys $(98 \%)$ of comparable size. Serum concentrations of $\mathrm{T}_{4}$ and $\mathrm{T}_{3}$ declined by 64-76 and 93-96\% relative to control values, respectively, in metamorphosing and nonmetamorphosing L. appendix treated with $\mathrm{KClO}_{4}$. PTU elicited declines of $55 \%$ for $\mathrm{T}_{4}$ and $80 \%$ for $\mathrm{T}_{3}$, but only one animal metamorphosed. Based on these data, we conclude that a decline in serum $\mathrm{TH}$ levels is necessary for metamorphosis in L. appendix, but not sufficient by itself to trigger the process.
\end{abstract}

Résumé : On trouvera ici la description des sept stades de métamorphose spontanée chez la lamproie (Lampetra appendix); nous avons évalué l'importance de la taille comme facteur déterminant de la métamorphose spontanée et de la métamorphose provoquée. Les concentrations sériques des hormones thyroïdiennes $(\mathrm{TH})$ thyroxine $\left(\mathrm{T}_{4}\right)$ et triiodothyronine $\left(\mathrm{T}_{3}\right)$ ont été mesurées chez des lamproies en métamorphose et chez d'autres lamproies non en métamorphose. La séquence des stades de métamorphose et les modifications de la longueur relative de la plupart des zones du corps correspondent aux données signalées pour d'autres espèces. Cependant, chez cette espèce, les lamproies prémétamorphiques et les lamproies en métamorphose au cours des premiers stades (1-3) sont de taille bien supérieure (au moins $155 \mathrm{~mm}$ et $5,40 \mathrm{~g}$ ) à celle mesurée chez d'autres espèces. Les concentrations sériques de $\mathrm{T}_{4}$ et de $\mathrm{T}_{3}$ sont élevées à la fin de la période larvaire et diminuent considérablement jusqu'au stade 2 de la métamorphose. Nous avons administré du perchlorate de potassium $\left(\mathrm{KClO}_{4} ; 0,01\right.$ et $\left.0,05 \%\right)$ ou $10 \mathrm{mg} / \mathrm{L}$ de propylthiouracil $(\mathrm{PTU} ; 0,0001 \%)$ à des larves de longueur $\geq 130 \mathrm{~mm}$ durant 117 jours, de septembre à janvier, afin de vérifier si ces goitrogènes peuvent provoquer la métamorphose chez les poissons. Les deux concentrations de $\mathrm{KClO}_{4}$ ont provoqué la métamorphose, mais la fréquence des métamorphoses $(62 \%)$ a été de beaucoup inférieure à celle enregistrée chez des Lamproies marines (98\%) de tailles semblables. Les concentrations sériques de $\mathrm{T}_{4}$ et de $\mathrm{T}_{3}$ ont subi des chutes de 64-76 et de 93-96\% par rapport aux valeurs témoins enregistrées chez les lamproies en métamorphose ou non traitées au $\mathrm{KClO}_{4}$. L'administration de PTU a entraîné une baisse de $55 \%$ de $\mathrm{T}_{4}$ et de $80 \%$ de $\mathrm{T}_{3}$, mais un seul animal s'est métamorphosé. D'après ces données, il faut que les concentrations sériques des hormones thyroïdiennes diminuent pour que la métamorphose ait lieu chez la lamproie, L. appendix, mais cette diminution ne suffit pas par elle-même à provoquer la métamorphose.

[Traduit par la Rédaction]

\section{Introduction}

All species of lampreys undergo a metamorphosis in which extensive morphological, physiological, and behaviourial changes occur (Youson 1988), followed by a speciesspecific parasitic or nonparasitic adult life. Most parasitic species migrate from their natal streams into large bodies of water, where they feed on the blood, body fluids, and (or) tissues of teleosts for 12-18 months, resulting in a rapid increase in size of juveniles. Sexual maturation is coincident with the cessation of feeding (1.5-2 years after metamorphosis) and an upstream migration and is followed by spawning

Received August 17, 1998. Accepted March 24, 1999.

J.A. Holmes, ${ }^{1}$ H. Chu, S.A. Khanam, R.G. Manzon, and J.H. Youson. Division of Life Sciences, University of Toronto at Scarborough, 1265 Military Trail, Scarborough, ON M1C 1A4, Canada.

${ }^{1}$ Author to whom all correspondence should be addressed (e-mail: holmes@scar.utoronto.ca). 
(Hardisty and Potter 1971). In contrast, nonparasitic species begin sexual maturation immediately after the completion of metamorphosis, foregoing a feeding interval, with spawning and death usually occurring the following spring. Thus, nonparasitic adults are smaller and less fecund than their parasitic counterparts and do not exhibit their migratory behaviour (Hardisty and Potter 1971).

Larval size (length in combination with mass) is an important determinant of whether sea lamprey larvae (Petromyzon marinus, a parasitic species) are likely to enter metamorphosis. Metamorphosis is a nontrophic interval in the lamprey life cycle (Potter 1980) and, in P. marinus, the catabolism of lipid is the primary energy source (Youson et al. 1979). In nonmetamorphosing sea lamprey larvae, lipids comprise, on average, about $4 \%$ of the live body mass, increasing to about $14 \%$ of the live body mass during the last year of larval life after the animal has reached a length comparable with that of metamorphosing animals (Lowe et al. 1973; O'Boyle and Beamish 1977). Although sea lamprey larvae in an anadromous population in New Brunswick, Canada, must be at least $110 \mathrm{~mm}$ (length) and $2.0 \mathrm{~g}$ (mass) in size prior to beginning metamorphosis (Potter et al. 1978), larvae in landlocked populations from the Great Lakes and Lake Champlain must be at least $120 \mathrm{~mm}$ (length) and $3.0 \mathrm{~g}$ (mass) in size (Youson et al. 1993). Because both metamorphosis and the subsequent period of sexual maturation are nontrophic in nonparasitic species, the larvae presumably have greater energy reserves prior to entering metamorphosis than those of parasitic species that feed between metamorphosis and spawning. If, as in sea lampreys, lipid is the primary energy store (Lowe et al. 1973; Kao et al. 1997), then animal size and condition might also be important requirements for metamorphosis in nonparasitic lampreys.

Thyroid hormones (TH) influence the events of metamorphosis in those teleost groups (Anguilliformes, Elopiformes, Notocanthiformes, and Pleuronectiformes) and amphibians (anuran and urodele) that exhibit a true metamorphosis. Thyroxine $\left(\mathrm{T}_{4}\right)$ and triiodothyronine $\left(\mathrm{T}_{3}\right)$ concentrations increase during spontaneous metamorphosis of amphibians and flounders, peaking at metamorphic climax (Inui and Miwa 1985; Galton 1988; Galton et al. 1994; Inui et al. 1994), and precocious metamorphosis can be induced in larvae with exogenous $\mathrm{T}_{4}$ and (or) $\mathrm{T}_{3}$ treatments (Inui and Miwa 1985; Miwa and Inui 1987; Galton 1988). In contrast, the initial stages of spontaneous metamorphosis in lampreys, particularly sea lampreys, are accompanied by a substantial decline in serum levels of both $\mathrm{T}_{4}$ and $\mathrm{T}_{3}$ (Wright and Youson 1977; Lintlop and Youson 1983; Leatherland et al. 1990; Youson et al. 1994). Precocious metamorphosis can be induced in some lamprey species with exogenous treatments of potassium perchlorate $\left(\mathrm{KClO}_{4}\right.$; Hoheisel and Sterba 1963; Suzuki 1986, 1989; Holmes and Youson 1993). $\mathrm{KClO}_{4}$ also depresses serum levels of both $\mathrm{T}_{4}$ and $\mathrm{T}_{3}$ (Suzuki 1986, 1989; Youson et al. 1995; Manzon and Youson 1997; Manzon et al. 1998), mimicking the situation in the early stages of spontaneous metamorphosis. However, treatment with propylthiouracil (PTU) produces mixed results; Suzuki (1986) reported complete metamorphosis in Lampetra reissneri, while Leatherland et al. (1990) were not able to induce metamorphosis in Geotria australis, despite the fact that larvae of the latter species exposed to PTU had significantly lower serum TH levels than untreated control animals. Thus, although TH probably do not regulate the initiation of lamprey metamorphosis in the manner described for teleosts and amphibians, they may be important for the synchrony of developmental processes during metamorphosis (Youson 1997).

In the present study, we compare spontaneous and induced precocious metamorphosis in the nonparasitic American brook lamprey, Lampetra appendix, in terms of the incidence of metamorphosis, the importance of size as a determinant of metamorphosis, and serum $\mathrm{T}_{4}$ and $\mathrm{T}_{3}$ concentrations in metamorphosing and nonmetamorphosing individuals. Although induced metamorphosis has previously been reported in brook lampreys (e.g., Lampetra planeri, Hoheisel and Sterba 1963; Lampetra reissneri, Suzuki 1986, 1989), there is no large-scale study of induced metamorphosis in any nonparasitic species where size and time of year have been carefully controlled and both serum $\mathrm{T}_{4}$ and $\mathrm{T}_{3}$ concentrations have been measured. We also provide the first descriptions of the stages of the normal metamorphic development (which we call spontaneous) in L. appendix.

\section{Materials and methods}

\section{Spontaneous metamorphosis}

In June 1995, L. appendix larvae were collected from Bowmanville Creek $\left(43^{\circ} 53^{\prime} \mathrm{N}, 78^{\circ} 40^{\prime} \mathrm{W}\right)$, a Lake Ontario tributary about $50 \mathrm{~km}$ east of Metropolitan Toronto, using DC backpack electrofishing gear, and transported to the University of Toronto at Scarborough. The larvae were maintained in a large fibreglass tank (152 (length) $\times$ 55 (width) $\times 35$ (height) $\mathrm{cm}$ ) and provided with $7-8 \mathrm{~cm}$ of sand for burrowing and aerated dechlorinated tap water, the temperature of which was changed seasonally. Photoperiod was held constant at $15 \mathrm{~h}$ light : $9 \mathrm{~h}$ dark before and during the experiment, because previous studies on sea lampreys did not detect a short-term photoperiod effect on metamorphosis (Cole and Youson 1981; Youson et al. 1993; Holmes et al. 1994), and larvae were fed baker's yeast once each week at the rate of $1 \mathrm{~g} /$ animal per week. Those animals in which spontaneous metamorphosis was initiated by July 1995 $(N=20)$ were measured for length and mass in the early stages of metamorphosis (stages 1,2, and 3), to estimate the minimum size (length and mass) required for premetamorphic larvae to begin spontaneous metamorphosis.

We sampled some of the metamorphosing L. appendix periodically throughout the summer and fall of 1995 to describe the stages of metamorphosis $(N=1$ or 2 per stage). Descriptions of stages 1-5 are based on animals collected from Bowmanville Creek. Stages 6-7 and adult specimens were collected from Duffins Creek, a Lake Ontario tributary about $10 \mathrm{~km}$ east of Metropolitan Toronto, in early September 1995, transported to our laboratory, and held under the conditions described above. Although the separation of metamorphosing animals into stages (stage 1 (earliest) to stage 7 (latest)) was based on live animals, using the criteria in Youson and Potter (1979) as a guide, our descriptions of the key characters are based on preserved specimens. We anaesthetized animals in 0.05\% MS-222 (tricaine methanesulfonate, Syndel Laboratories, Vancouver, B.C.), recorded total length $( \pm 1 \mathrm{~mm})$ and mass $( \pm 0.01 \mathrm{~g})$, and then fixed and preserved examples of premetamorphic larvae, each metamorphic stage, and maturing adults in $5 \%$ formalin. The following body regions (Potter et al. 1980) were measured $( \pm 0.01 \mathrm{~mm})$ 29-36 months after preservation: length of the oral disc, prebranchial length, branchial length, eye diameter, trunk length, trunk depth, cloaca length, tail length, and the heights of the first and second dorsal fins ( $N=1$ or 2 per stage). These measurements were converted to relative lengths (percent), using the 
total length of the preserved animal. Sagnes (1997) investigated the effects of $4 \%$ formalin preservation on larval Arctic grayling (Thymallus thymallus) and found that shrinkage of body regions measured along the axis of total length were proportionately comparable with shrinkage in total length, and that changes in body depth due to preservation (similar to our measurement of lamprey trunk diameter) were insignificant. We assume that changes due to preservation are equivalent in all body regions, so we did not attempt to correct our data to represent fresh-specimen lengths.

Larvae and spontaneously metamorphosing L. appendix were collected from Duffins Creek between 21 June and 22 August 1996 and transported to our laboratory at the University of Toronto at Scarborough for blood collection. Water temperatures (based on instantaneous measurements) varied between 14 and $17^{\circ} \mathrm{C}$ at the time of collection. The stage 1 animals were collected 1 year earlier, on 18 July 1995, from the same location. On the same day that they were collected, the animals were anaesthetized in $0.05 \%$ MS222 , length $( \pm 1 \mathrm{~mm})$ and mass $( \pm 0.01 \mathrm{~g})$ were measured, stage of metamorphosis was assessed (Youson and Potter 1979), and blood was collected in heparinized microcapillary tubes following caudal severance. The blood was clotted overnight at $4^{\circ} \mathrm{C}$ and centrifuged the next morning, and the serum was separated and stored at $-70^{\circ} \mathrm{C}$ for later determination of serum TH concentrations.

\section{Induced metamorphosis}

Lampetra appendix larvae $\geq 130 \mathrm{~mm}$ long $(N=150)$ from Bowmanville Creek that did not enter spontaneous metamorphosis by August 1995 were randomly sorted into small experimental tanks $(40 \times 20 \times 25 \mathrm{~cm})$ at a density of 10 animals/tank $(125$ animals/ $\mathrm{m}^{2}$ ) on 13 September 1995. Each tank was supplied with $10 \mathrm{~L}$ of static aerated dechlorinated tap water at room temperature and 6$7 \mathrm{~cm}$ of sand for burrowing, and was kept at a photoperiod of $15 \mathrm{~h}$ light : $9 \mathrm{~h}$ dark throughout the experiment. Experimental treatments (three replicate tanks per treatment) consisted of 0.01 and $0.05 \% \mathrm{KClO}_{4}$ (Aldrich Chemical Co., Milwaukee, Wis.), $10 \mathrm{mg} / \mathrm{L}$ PTU (0.0001\%; Sigma Chemical Co., St. Louis, Mo.), a dechlorinated tap water control, and a $0.1 \mathrm{M} \mathrm{NaOH}(50 \mathrm{~mL} / 10 \mathrm{~L})$ control. The $\mathrm{NaOH}$ control was necessary, because PTU is only soluble in an alkaline solution; Manzon and Youson (1997) subsequently demonstrated that $\mathrm{NaOH}$ has no effect on the incidence of metamorphosis in sea lampreys. These treatments and their concentrations were similar to those used in previous studies of induced metamorphosis in lampreys (e.g., Leatherland et al. 1990; Holmes and Youson 1993; Manzon and Youson 1997).

The experiment began 13 September 1995 and was terminated 8 January 1996. Since the tanks were static, the water was changed and the goitrogens refreshed with the addition of $50 \mathrm{~mL}$ of stock solutions every 2 weeks. Water temperature (instantaneous measurement) was checked and recorded twice a day, and observations of mortality and external signs of metamorphosis in animals visible above the sand were recorded at the same time. To maintain animal density in the tanks, dead animals were replaced with animals marked with a subcutaneous injection of yellow latex dye in the caudal sinus. At the end of the experiment, the animals were anaesthetized in $0.05 \%$ MS-222, length $( \pm 1 \mathrm{~mm})$ and weight $( \pm 0.01 \mathrm{~g})$ were measured, stage of metamorphosis was assessed (Youson and Potter 1979), and blood was collected; the serum was separated and stored for later determination of serum $\mathrm{TH}$ concentrations as previously described.

Water temperature in the experimental tanks was held between 16 and $21^{\circ} \mathrm{C}$ during the study, averaging $18.6^{\circ} \mathrm{C}\left(\mathrm{SE}= \pm 0.05^{\circ} \mathrm{C}\right)$. These temperatures $\left(16-21^{\circ} \mathrm{C}\right)$ were higher than seasonal temperatures in Toronto area streams during the study period, but were within the normal temperature range for spontaneous metamorphosis (Youson et al. 1993) and the most effective for inducing metamorphosis by $\mathrm{KClO}_{4}$ in sea lampreys (R.G. Manzon and J.H. Youson, unpublished data). Despite the high temperatures, mortal- ity was low during the induction experiment, consisting of two larvae in control tanks $(6.7 \%)$.

\section{Serum TH measurement}

TH concentrations were measured using Amersham Amerlex commercial radioimmunoassay (RIAs) kits for $\mathrm{T}_{4}$ and $\mathrm{T}_{3}$ that were modified as described by Leatherland et al. (1990). Serum samples for both $\mathrm{T}_{4}$ and $\mathrm{T}_{3}$ were thawed and dispensed into duplicate aliquots of $2.5 \mu \mathrm{L}$ for measurement. When the volume of serum collected from a single animal was not sufficient for both assays, samples from 2-3 animals were pooled to obtain the necessary volume. Thus, sample sizes $(N)$ correspond to the number of samples assayed rather than the number of animals from which serum was collected. Duplicate measurements were accepted if the difference between the gamma count of each aliquot was $\leq 10 \%$ of the count for the zero standard (which contains ${ }^{125} \mathrm{I}$ and antibody but no $\mathrm{T}_{4}$ or $\mathrm{T}_{3}$ ). Serum samples from the induction experiment and from spontaneously metamorphosing animals were analyzed more than 1 year apart by different individuals. Assay sensitivities for sera collected from the induction experiment were $14.4 \mathrm{nmol} / \mathrm{L}$ for $\mathrm{T}_{4}$ and $0.26 \mathrm{nmol} / \mathrm{L}$ for $\mathrm{T}_{3}$, and intra- and inter-assay variation was $<12 \%$ for $\mathrm{T}_{4}$ and $<12 \%$ for $\mathrm{T}_{3}$. Assay sensitivities for sera collected from spontaneously metamorphosing $L$. appendix were $12 \mathrm{nmol} / \mathrm{L}$ for $\mathrm{T}_{4}$ and $0.25 \mathrm{nmol} / \mathrm{L}$ for $\mathrm{T}_{3}$, and the inter- and intra-assay variation was $<9.5 \%$ for both $T_{4}$ and $T_{3}$. Serum $T_{4}$ concentrations in sea lampreys exposed to $\mathrm{KClO}_{4}$ or PTU or in spontaneously metamorphosing lampreys at stages 4 and 5 were below the detection limits of the $\mathrm{T}_{4}$ assay. For these samples, we increased the serum volume to $10 \mu \mathrm{L}$ and divided the measured values by the concentration factor (4) to obtain the concentrations reported.

\section{Data analysis}

We used the length and mass data from fresh specimens of L. appendix to document gross body changes during metamorphosis.

Predictions of the incidence of metamorphosis in L. appendix were based on the minimum size (length and mass) and condition factor (CF) of spontaneously metamorphosing L. appendix in the summer of 1995. This approach has been used to successfully predict sea lamprey metamorphosis in the laboratory (Holmes and Youson 1993, 1997; Youson et al. 1993; Holmes et al. 1994). CF was calculated as (mass $(\mathrm{g})) /(\text { length }(\mathrm{mm}))^{3} \times 10^{6}$. An animal that met the size and CF criteria at the beginning of the experiment was expected to initiate metamorphosis when induced by the goitrogen treatments. We compared these predictions with the observed incidence of metamorphosis, to determine if a minimum size and physiological conditioning were requirements of induced metamorphosis in L. appendix.

The incidence of metamorphosis among the different treatments was assessed by one-way ANOVA. Multiple comparisons of treatment means were made using Scheffé's $S$ test, and these data are reported as the mean $\pm 1 \mathrm{SE}$. Chi-squared analysis was used to compare the expected number of metamorphosing animals with the observed number of metamorphosing animals in each tank. Because the larvae used in our study ranged in length from 130 to $178 \mathrm{~mm}$, we used linear regression to determine if $\mathrm{TH}$ concentration was a function of animal mass for a treatment. When significant linear relationships were found, we used analysis of covariance (ANCOVA) to adjust the mean TH levels, removing the effect of mass prior to analyzing the $\mathrm{T}_{3}$ data by one-way ANOVA. The $\mathrm{T}_{4}$ data were also analyzed by one-way ANOVA, but the data from the $\mathrm{KClO}_{4}$ treatments were omitted from this analysis, because they were below the detection limits of the assay and so we are uncertain of the real values. Results are accepted as significant if $P \leq$ 0.05 . Since the RIAs for serum TH concentrations in spontaneously metamorphosing animals and those from the induction ex- 
Fig. 1. The anterior region of Lampetra appendix in premetamorphic larvae (A and B), metamorphosing stages 1 (C), 3 (D), 5 (E), and $7(\mathrm{~F})$, and sexually maturing adults $(\mathrm{G}$ and $\mathrm{H})$. All lateral (A and $\mathrm{C}-\mathrm{G})$ and ventral $(\mathrm{B}$ and $\mathrm{H})$ views are of specimens preserved in $5 \%$ formalin for 34-36 months.
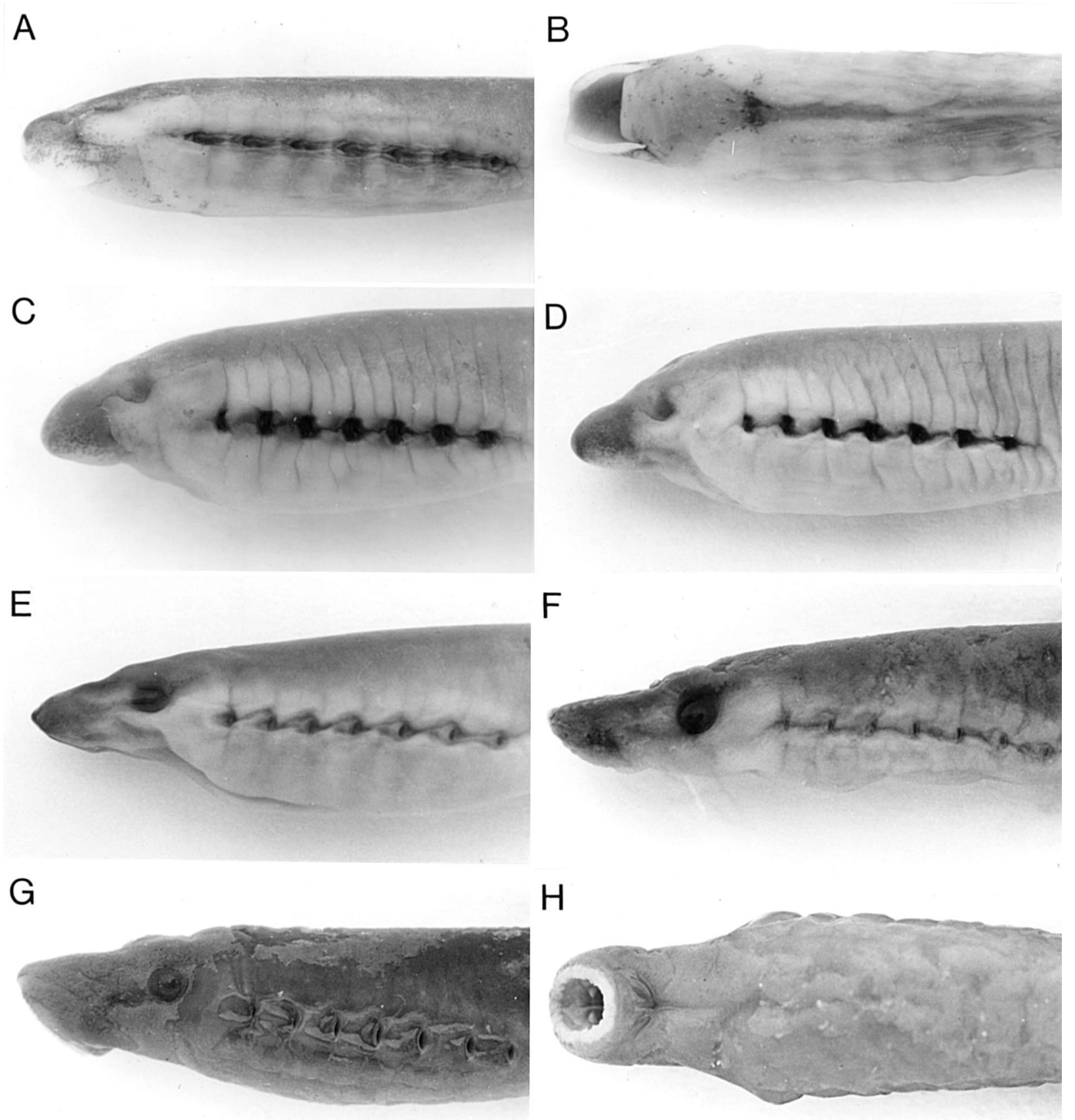

periment were conducted more than 1 year apart by different individuals, we did not directly compare $\mathrm{T}_{4}$ and $\mathrm{T}_{3}$ values.

\section{Results}

\section{Spontaneous metamorphosis}

\section{Description of stages}

Larva (Figs. 1A and 1B)-The anterior end of a larva is dominated by the oral hood, which consists of a pair of thin

lateral lips and a thicker ventral transverse lip. When viewed ventrally, large branched cirrhi can be seen prominently in the posterior portion of the hood around the buccal funnel (posterior cirrhi). The dorsal surface of the oral hood is covered with much smaller unbranched projections that are not easily seen, the anterior cirrhi. The incompletely developed eyes are small, irregularly shaped, and located dorsally at the level of the transverse lip. The branchiopores are triangular in shape, with the apex pointing anteriorly, and are connected by a longitudinal groove. The dorsal half of the body is pigmented, but pigmentation is absent from the gill 
region and, laterally, from both sides of the head and the lower half of the lateral lips.

Stage 1 (Fig. 1C)-Metamorphosis of L. appendix begins in early July with the appearance of stage 1, which is characterized by two features: $(i)$ an enlargement of the eye to a more regular shape and (ii) a dorsoventral enlargement of the branchial region. In this stage, the oral hood is shorter than in the larva and is beginning to fold under, so that the opening is subterminal. These changes are accompanied by a thickening of the lateral lips forming the oral hood of the larva and a reduction in the width of the transverse lip. The posterior cirrhi in the oral cavity are more clearly visible than in the larva, particularly those lateral to the buccal funnel, and the anterior cirrhi seem to be fewer in number but larger than in the larva. Other features, such as the branchiopores, body pigmentation, and the presence of oral cirrhi, retain their larval configurations.

Stage 2-The second stage of metamorphosis appears toward the end of July. In this stage, the lateral lips are thicker and the oral opening is smaller than in the larva, and the transverse lip has become trapezoidal in shape. The anterior oral cirrhi are larger than in stage 1, and some appear to be clumping together to form larger buds. The posterior cirrhi are less prominent in size and the branching appears to be reduced. The snout has a rounded triangular shape in both dorsal and lateral views. The eye is more clearly developed and larger than in stage 1 , and the beginning of a notch is evident at the cloaca (cloacal notch).

Stage 3 (Fig. 1D) - The eye is circular rather than oval as in earlier stages and is differentiated into the iris and pupil for the first time. The lips are thick and completely encircle the presumptive oral disc, but grooves are present between the transverse and lateral lips, indicating that they have not fused. The anterior cirrhi are again larger and by this stage appear as large papillae. In contrast, the posterior cirrhi are greatly reduced in size and number relative to the larval condition. The branchial region remains enlarged, but the branchiopores start to lose their triangular larval appearance and acquire an oval shape, and the longitudinal groove connecting them is less prominent. Stage 3 animals appear by early August.

Stage 4-Animals in stage 4 of metamorphosis appear between early and mid-August. The most prominent feature of these animals is that the lateral and transverse lips are fused and form a complete ring of tissue supporting an ovalshaped oral disc that is narrower than the head and snout of the animal. A tongue-like piston has begun to develop deep in the oral cavity, and only 2 or 3 posterior cirrhi are visible lateral to the buccal funnel. The anterior papillae seem to be fewer in number and more rounded in shape than at earlier stages of metamorphosis. In stage 4 , the eye is larger than in stage 3, being about one-third the depth of the head. The branchiopores are now narrow oval slits, and there is little evidence of the longitudinal groove. However, the branchial region continues to exhibit the dorsoventral enlargement. Body pigmentation has increased on the dorsal and lateral surfaces of the head and snout.
Stage 5 (Fig. 1E)-The snout is strongly triangular in shape in both dorsal and lateral views. The ring supporting the oral disc is smoothly fused with no grooves present, although there is a triangular notch distal to the oral disc on the ventral surface. The piston is clearly visible in the oral disc and consists of two lateral lingual laminae and a transverse lingual lamina. The supraoral and infraoral laminae are visible as smooth white structures surrounding the buccal funnel. Although none of the laminae have obvious tooth development, papillae on the oral disc have increased in size and points have begun to develop on them. The edge of the oral disc has a fringed appearance, owing to the development of fimbriae. The cloacal notch is well-developed and both dorsal fins are greatly enlarged vertically. Late August to early September is the time when animals at this stage of metamorphosis can be captured.

Stage 6-The branchiopores are clearly oval in shape and the longitudinal groove connecting them has disappeared. Dorsoventral expansion of the branchial region is not as prominent as in earlier stages of development. Prominent fimbriae encircle the outer ring of the oral disc, and tooth development is clearly visible in the oral cavity. The supraoral lamina is prominent and two lateral cusps are visible; the infraoral lamina possesses six raised points. The teeth developing closest to the buccal funnel (circumoral teeth) are bicuspid, while the other teeth, which are smaller, are unicuspid. The posterior portion of the oral disc folds into the ventral triangular notch, so that the oral disc remains narrower than the triangular head. Body pigmentation has continued to increase. Metamorphosing L. appendix reach stage 6 by midSeptember.

Stage 7 (Fig. 1F) - Stage 7 of metamorphosis begins in October. The bicuspid circumoral teeth are about twice the size of the other teeth, which are unicuspid. The infraoral lamina, although difficult to see ventrally, has six cusps. Neither of the laminae on the piston appears to have cusps by stage 7 . Although the oral disc is somewhat open, it remains narrower than the head and oval in shape. The branchial openings are oval and the enlargement of the branchial region is no longer obvious. The eye has enlarged to about one-half the depth of the head. Body colouration has continued to darken but has begun to appear blotchy, particularly laterally near the ventral surface. The cloacal notch is quite prominent, owing to anterior swelling along the midline and a sharp ridge running posteriorly from the cloaca to the caudal fin.

Maturing adult (Figs. $1 \mathrm{G}$ and $1 \mathrm{H}$ )-Immature adults, which began to appear in December, have a fully developed circular oral disc. Prominent fimbriae fringe the outer edge of the disc and tooth cusps are prominent: in preserved specimens they are orange-brown in colour and curve inwards toward the buccal funnel. The inner surfaces of the lateral lingual lamina have conspicuous spines, which give a serrated appearance to the piston, and three cusps are visible on the transverse lingual lamina. The infraoral lamina has six cusps, while the lateral cusps of the supraoral lamina are more prominent than in earlier stages of metamorphic development. The eye is large and well-developed, accounting for about one-third of the depth of the head. The gill openings are oval and body pigmentation is darker and blotchy. The 
Fig. 2. Changes in total length (A) and mass (B) of metamorphosing Lampetra appendix. Stage L indicates untransformed larvae exceeding the minimum size for metamorphosis (155 $\mathrm{mm}$ and $5.40 \mathrm{~g}$ ) in June 1995, and stages $1-6$ are as described in the text. Sample sizes $(N)$ for stages $L$, $1,2,3,4,5$, and 6 are $22,5,6,3,3,18$, and 18 , respectively.
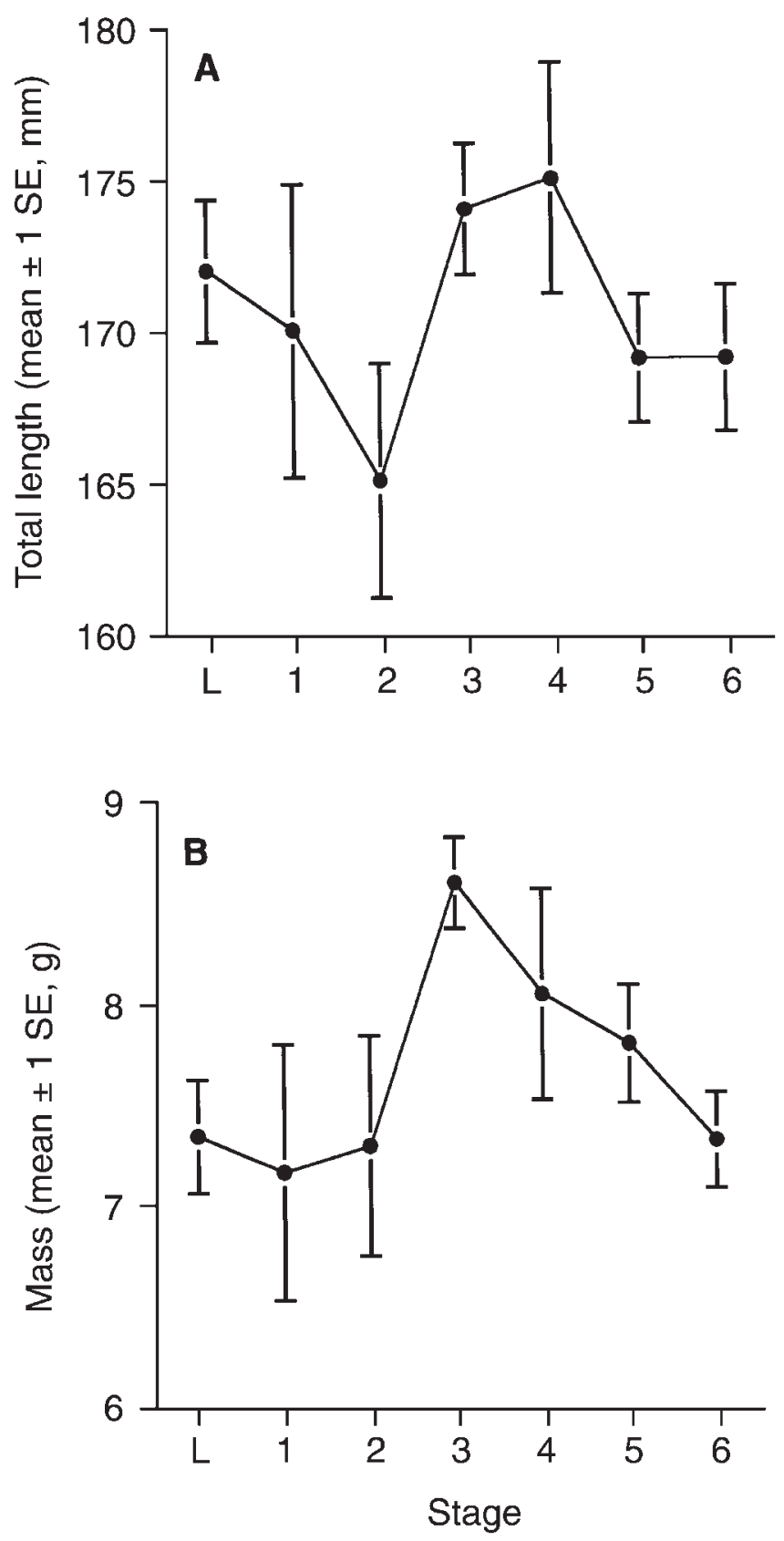

cloacal notch is extremely pronounced, with the anterior lips swollen and the posterior ridge more prominent than in previous stages. The dorsal fins are large and erect.

\section{Size at metamorphosis}

In the early stages of metamorphosis in July and August 1995 (stages 1-3), L. appendix ranged from 155 to $189 \mathrm{~mm}$ in length and from 5.40 to $9.74 \mathrm{~g}$ in mass. Although there were no significant changes in length during metamorphosis
(Fig. 2A), stage 3 animals were significantly heavier than nonmetamorphic larvae at the beginning of metamorphosis or animals in stages 1 and 2 of metamorphosis (Fig. 2B). By stages 5 and 6 , metamorphosing animals were significantly lighter than those in stage 3. For L. appendix in stages 1, 2, or 3 of metamorphosis, the average values for size were $176 \pm$ $2.26 \mathrm{~mm}$ (length $\pm \mathrm{SE}$ ) and $7.56 \pm 0.25 \mathrm{~g}$ (mass $\pm \mathrm{SE}$ ) and the average $\mathrm{CF}$ was $1.39 \pm 0.023$. For spontaneously metamorphosing $L$. appendix, the minimum values for size were $155 \mathrm{~mm}$ (length) and $5.40 \mathrm{~g}$ (mass) at stage 1 and the minimum CF was 1.25 at stage 3 . These minima were used to predict metamorphosis in the induction study.

\section{Morphological evaluation}

Although caution is necessary because of the small sample sizes ( $N=1$ or 2 at each stage), the most obvious external morphological changes during metamorphosis in L. appendix are the development of the eye and the oral disc (Fig. 1). The eye doubled in diameter (given as a percentage of total length) from about $0.6 \%$ in the larva to $1.2 \%$ at stage 1 , and doubled again from stage 1 to the adult (about 2\%) (Fig. 3A). The initial stages of development of the oral disc involved a reduction in the size of the opening followed by a rapid increase in length after stage 5 (Fig. 3A). These changes in the eye and oral disc were accompanied by an increase in the length of the prebranchial region (Fig. 3B). At the same time, a slight decrease in the length of the branchial region was observed between the larval phase and stage 5 of metamorphosis (Fig. 3B). In L. appendix, trunk depth increased throughout metamorphosis, from the larval to the adult stage (Fig. 3D), while trunk length exhibited no consistent pattern of change (Fig. 3C). The length of both the tail and the cloacal slit decreased during metamorphosis (Figs. 3C and 3D). Another prominent morphological change during metamorphosis was a doubling in height of the first and second dorsal fins (Fig. 3E). The second dorsal fin was usually at least twice the height of the first dorsal fin at all stages.

\section{Serum TH hormone concentrations}

Concentrations of both $\mathrm{T}_{4}$ and $\mathrm{T}_{3}$ in the serum of $L$. appendix increased significantly between nonmetamorphic (i.e., larvae $<155 \mathrm{~mm}$ long) and premetamorphic larvae (those $\geq 155 \mathrm{~mm}$ long; Fig. 4). Concentrations of both $\mathrm{T}_{4}$ and $\mathrm{T}_{3}$ declined significantly (about $90 \%$ ) by stage 2 and then remained relatively constant up to stage 6 of metamorphosis, the last stage for which we have data.

Since serum for stage 1 was collected 1 year earlier than serum for the other stages, the mean $T_{4}$ and $T_{3}$ concentrations in stage 1 animals are treated separately from those of the other stages (shown in Fig. 4). Mean $\mathrm{T}_{4}$ concentration peaked in animals in stage 1 ; in contrast, mean $\mathrm{T}_{3}$ levels peaked in premetamorphic larvae. This high $\mathrm{T}_{4}$ level in stage 1 animals represents a doubling of the average levels found in the oldest premetamorphic larvae of similar size.

\section{Induced metamorphosis}

\section{Size at metamorphosis}

The size of larval L. appendix did not vary significantly between treatments in September 1995 (length: $F_{[4,145]}=$ $0.317, P=0.87$; mass: $\left.F_{[4,145]}=0.464, P=0.76\right)$, with aver- 


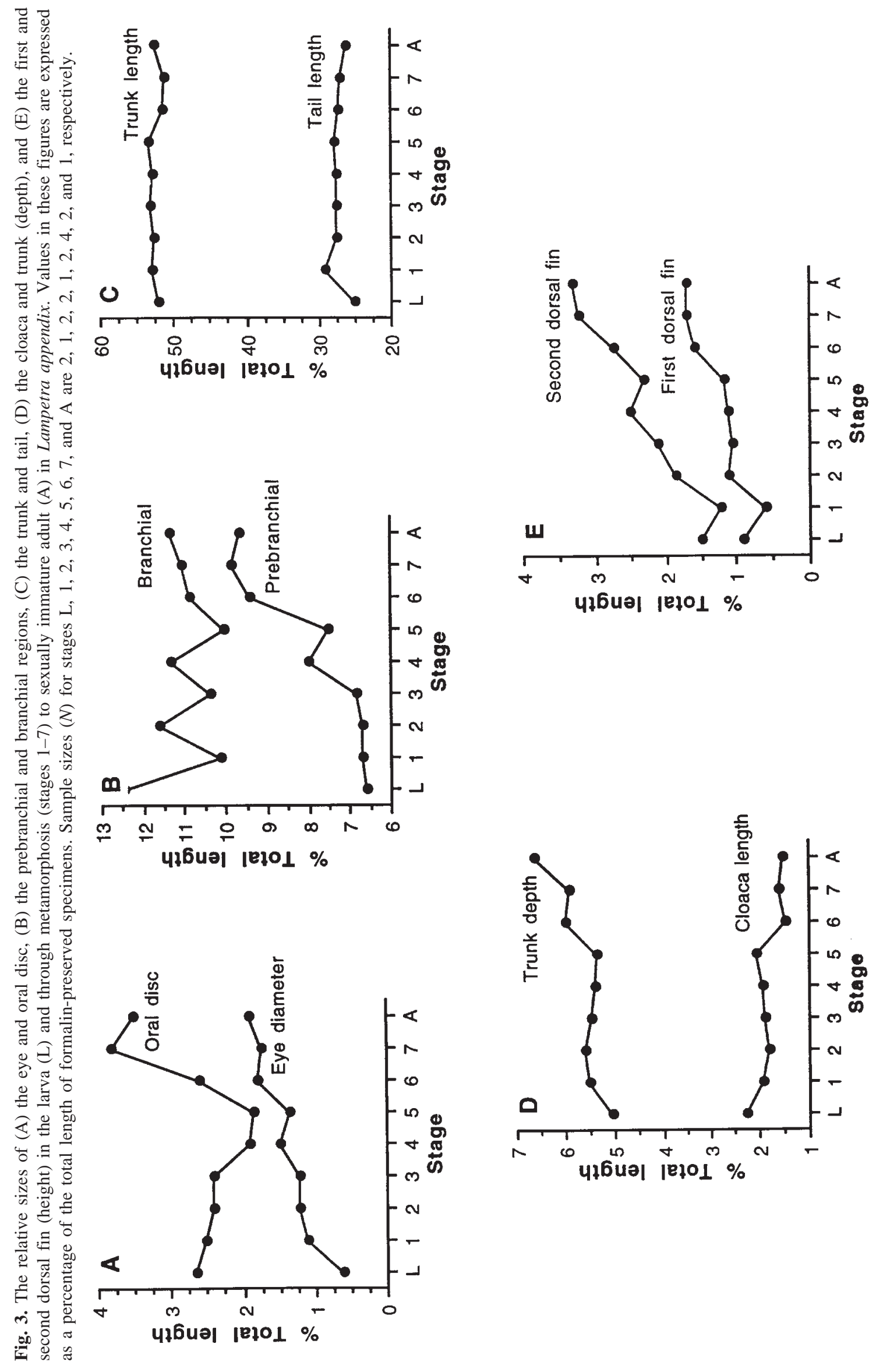


Fig. 4. Serum concentrations of $(A)$ thyroxine $\left(T_{4}\right)$ and (B) triiodothyronine $\left(\mathrm{T}_{3}\right)$ in spontaneously metamorphosing Lampetra appendix; NM, nonmetamorphosing larvae $(<155 \mathrm{~mm}$ long); PM, premetamorphic larvae ( $\geq 155 \mathrm{~mm}$ long); stages 1-5, see text. Sample sizes $(N)$ for NM and PM are 5 and 26 , respectively, and for stages $1,2,3,4$, and 5 are 5, 6, 3, 3, and 18 , respectively.
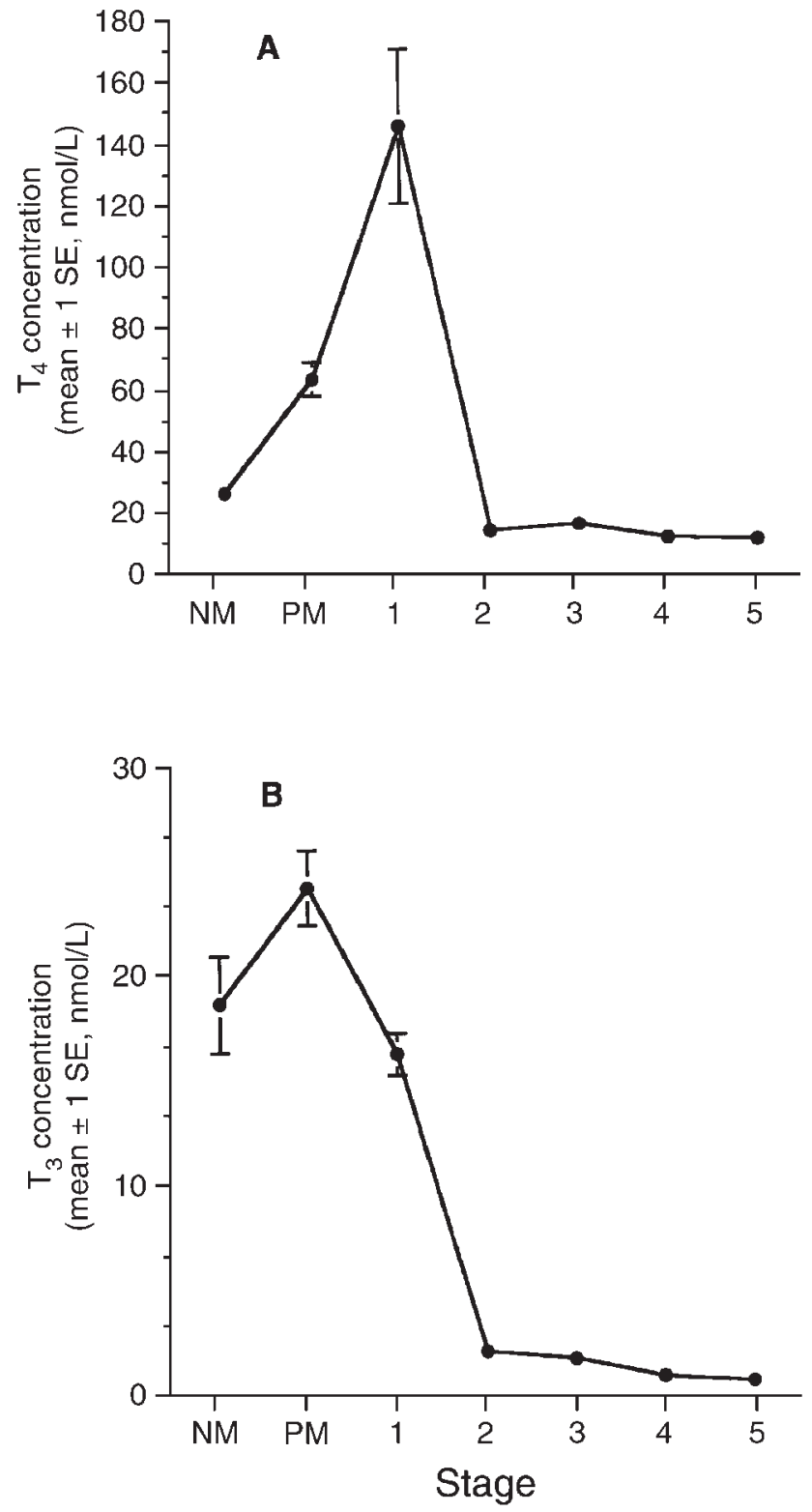

age values for length and mass of $151 \pm 0.897 \mathrm{~mm}$ and $4.73 \pm$ $0.083 \mathrm{~g}$, respectively. In September 1995, values for CF ranged from 1.34 to 1.37 , with an average of $1.36 \pm 0.005$. By January, metamorphosing animals were significantly larger than nonmetamorphosing larvae $(P<0.05)$, averaging $153 \pm 1.55 \mathrm{~mm}$ and $4.19 \pm 0.12 \mathrm{~g}$ in length and mass, respectively, with an average $\mathrm{CF}$ of $1.17 \pm 0.01$. Average values for size for nonmetamorphosing larvae were $143 \pm$ $1.16 \mathrm{~mm}$ (length) and $3.63 \pm 0.09 \mathrm{~g}$ (mass) and average $\mathrm{CF}$ was $1.20 \pm 0.007$. The smallest metamorphosing animal appeared to be in stage 1, was $132 \mathrm{~mm}$ long, weighed $2.46 \mathrm{~g}$, and had a CF of 1.06 .
Fig. 5. Number of individuals metamorphosing among Lampetra appendix exposed to different goitrogen treatments (present study) and among sea lampreys (Petromyzon marinus) exposed to two concentrations of $\mathrm{KClO}_{4}$ (results from 0.01 and $0.05 \%$ combined; from Holmes and Youson 1993). Means for L. appendix with different numbers of asterisks $(*)$ differ significantly from each other $(P \leq 0.05)$.

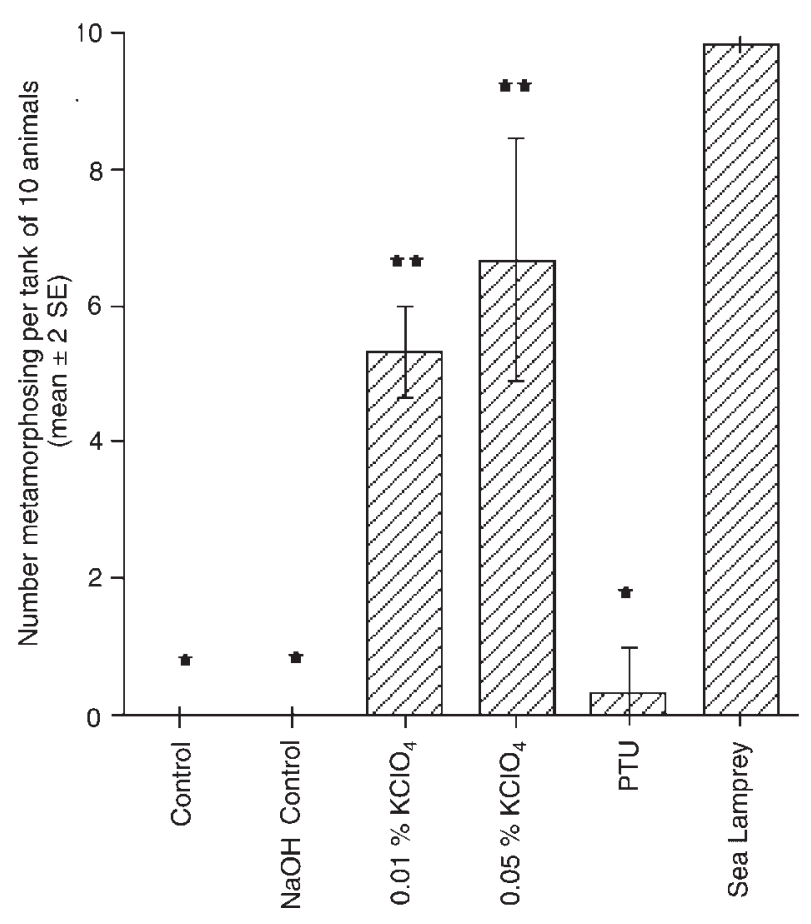

Incidence of metamorphosis

The incidence of induced metamorphosis was strongly influenced by the treatment that $L$. appendix larvae received $\left(F_{[4,10]}=53.2, P=0.0001\right)$. Significantly more animals initiated metamorphosis when treated with $\mathrm{KClO}_{4}(60 \%$ or $36 / 60$ exposed larvae) than when treated with PTU, $\mathrm{NaOH}$, or untreated water (Fig. 5). Although more larvae tended to enter metamorphosis when exposed to $0.05 \% \mathrm{KClO}_{4}(6.67 \pm$ 0.88 larvae/tank or $67 \%$ ) than when exposed to $0.01 \%$ $\mathrm{KClO}_{4}(5.33 \pm 0.33$ larvae/tank or $53 \%)$, the difference was not statistically significant $(P>0.05)$. Only one animal exposed to PTU initiated metamorphosis $(3.3 \%)$, and none of the animals in either control treatment $(\mathrm{NaOH}$ or untreated water) initiated metamorphosis.

From the minimum size and CF criteria from spontaneously metamorphosing animals, we predicted that 5 animals among the untreated controls (17\%) would enter metamorphosis; that 8, 9, and 10 animals in the $\mathrm{NaOH}(27 \%), 0.05 \%$ $\mathrm{KClO}_{4}(30 \%)$, and PTU $(33 \%)$ treatments, respectively, would enter metamorphosis; and that 11 animals (37\%) in the $0.01 \% \quad \mathrm{KClO}_{4}$ treatment would enter metamorphosis (Fig. 6). Significantly more larvae metamorphosed $(67 \%)$ than expected when treated with $0.05 \% \mathrm{KClO}_{4}(P<0.05)$, but there was no significant difference between predicted $(53 \%)$ and observed rates of metamorphosis when larvae were treated with $0.01 \% \mathrm{KClO}_{4}(P>0.05)$. The number of animals expected to metamorphose in the PTU and $\mathrm{NaOH}-$ and untreated-control treatments was significantly greater 
Fig. 6. Comparison of the number of observed and predicted metamorphosing Lampetra appendix. Predictions are based on minimum values for size of $155 \mathrm{~mm}$ (length) and $5.40 \mathrm{~g}$ (mass) and for $\mathrm{CF}$ of 1.25 at the beginning of the study. Observed values differing significantly from predicted values are indicated by an asterisk (*).

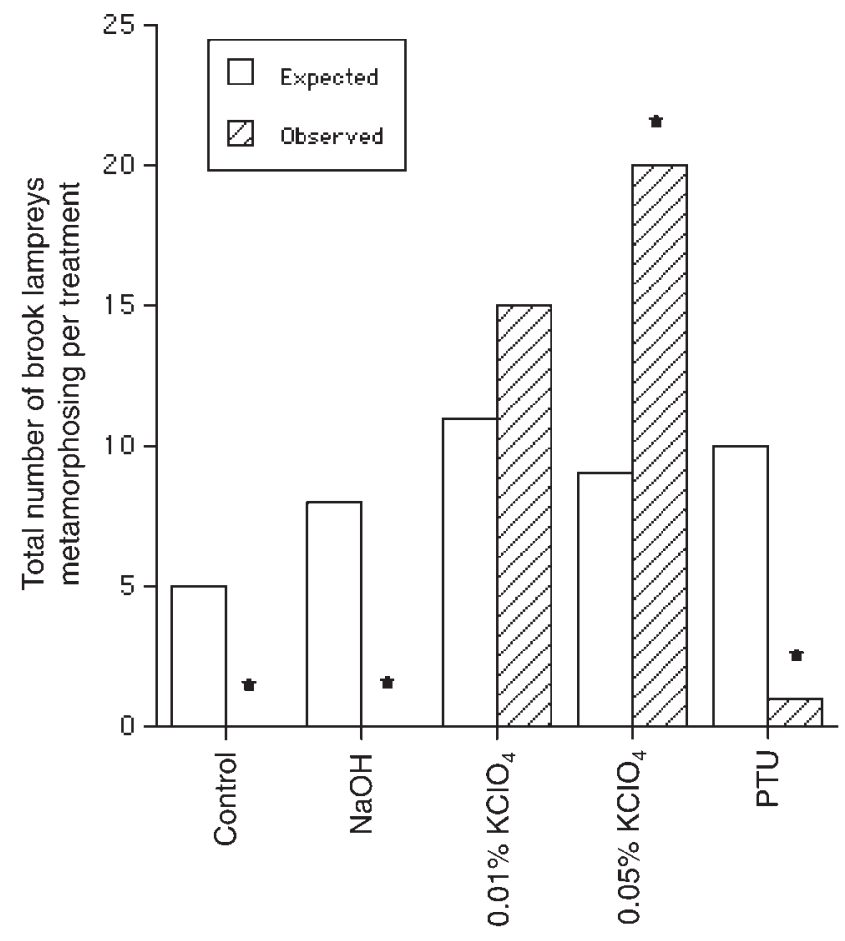

than the number observed $(P<0.05)$, but metamorphosis was not expected in the control treatments $(\mathrm{NaOH}$ and untreated water) given the timing of the study.

\section{Development}

External morphological changes appeared to be uncoordinated in L. appendix induced into metamorphosis compared with the features of each stage in spontaneous metamorphosis. For example, some animals had eye development characteristic of stage 5 in metamorphosis, while oral disc development lagged behind at approximately stage 3 . Some specimens exhibited greater differences, with features characteristic of stages 1 and 4 of spontaneous metamorphosis appearing in the same individual at the same time. When we terminated this study, individuals with metamorphosing features characteristic of stages 1-6 were present within the same treatments and even within the same replicate tanks.

\section{Serum concentrations of $T H$}

Significant positive relationships between mass and serum $\mathrm{T}_{4}$ and $\mathrm{T}_{3}$ concentrations in $L$. appendix were found in the $\mathrm{NaOH}$ - and untreated-control treatments for both hormones. These data were adjusted to the mean mass of all animals in a treatment (untreated control, $3.47 \mathrm{~g}$; $\mathrm{NaOH}$ control, $3.73 \mathrm{~g}$ ) using ANCOVA, and these adjusted values were used in subsequent analyses.

Treatment with the goitrogens PTU and $\mathrm{KClO}_{4}$ for 117 days significantly depressed serum $\mathrm{T}_{3}$ levels $\left(F_{[4,135]}=\right.$ $19.53, P=0.0001$ ) in both metamorphosing (by 95-96\%) and nonmetamorphosing (by 93-95\%) L. appendix, relative to levels in animals from the $\mathrm{NaOH}$ and untreated controls (Table 1). Average serum $\mathrm{T}_{3}$ concentrations were significantly lower in animals treated with $0.05 \% \mathrm{KClO}_{4}$ than in those treated with $0.01 \% \mathrm{KClO}_{4}\left(F_{[1,51]}=9.39, P=0.0035\right)$. Metamorphosing animals had significantly lower serum $\mathrm{T}_{3}$ concentrations than treated larvae that did not metamorphose, regardless of the $\mathrm{KClO}_{4}$ treatment $\left(F_{[1,51]}=15.62, P=\right.$ 0.0002). Nonmetamorphosing larvae and metamorphosing animals exposed to PTU had significantly higher serum $\mathrm{T}_{3}$ levels than those exposed to $\mathrm{KClO}_{4}$, but these levels were depressed significantly (by $80 \%$ ) relative to serum levels in untreated control larvae.

Treatment with $\mathrm{KClO}_{4}$ for 117 days depressed serum $\mathrm{T}_{4}$ levels in both nonmetamorphosing larvae and metamorphosing animals (Table 1) to below the detection limits of the assay $(14.4 \mathrm{nmol} / \mathrm{L})$. Thus, the estimates of $\mathrm{T}_{4}$ concentrations from animals in these treatments are less reliable than values for the controls, which were well above the detection limit. The $95 \%$ confidence interval for the mean $\mathrm{T}_{4}$ value in the $\mathrm{NaOH}$ control was $22.8-34.1 \mathrm{nmol} / \mathrm{L}$ and in the untreated control was 25.0-39.5 nmol/L. Since the lower limit of the assay was well outside these confidence intervals, we infer that reductions in serum $\mathrm{T}_{4}$ concentrations in $L$. appendix exposed to $\mathrm{KClO}_{4}$ relative to the control values were probably statistically significant. The $55 \%$ reduction in serum $\mathrm{T}_{4}$ levels in nonmetamorphosing larvae exposed to PTU was significantly less than the reduction in larvae from the $\mathrm{NaOH}$ or untreated controls $\left(F_{[2,77]}=10.72, P=0.0001\right)$.

\section{Discussion}

Although we described separate and distinct stages of metamorphosis in L. appendix, we recognize that each stage represents a phase on a continuum of development. The seven stages of metamorphosis are based on external morphological features and have been applied to both parasitic and nonparasitic lamprey species (e.g., Youson and Potter 1979; Bird and Potter 1979a; Potter et al. 1980). Bird and Potter $(1979 a)$ described the timing and stages of metamorphosis in the paired species Lampetra fluviatilis (parasitic) and L. planeri (nonparasitic) based on a sequence of nine stages, two of which are clearly postmetamorphic (i.e., the animals were distinguished on the basis of gonadal development and spawning status). We found that there were marked similarities between L. appendix (a nonparasitic species), L. planeri (Bird and Potter 1979a), and other lamprey species representing genera from all three extant families of lampreys in all but a few features of development during metamorphosis. For example, by stage 3 the eye is circular and clearly differentiated into the iris and pupil in all lamprey species examined (e.g., Potter et al. 1978, 1980; Bird and Potter 1979a; Youson and Potter 1979). These changes are coincident with internal changes in the eye (MeyerRochow and Stewart 1996). During stages 4-6, the body colouration becomes more polar, with the dorsal surface appearing darker and the ventral surface appearing lighter. There were only minor differences in the morphology of metamorphosis between L. planeri and L. appendix and other lampreys. The piston appears by stage 3 in G. australis and L. fluviatilis (Bird and Potter 1979a; Potter et al. 1980) and by stage 4 in $P$. marinus, L. planeri, and L. appendix 
Table 1. Concentrations (nmol/L) of thyroxine $\left(\mathrm{T}_{4}\right)$ and triiodothyronine $\left(\mathrm{T}_{3}\right)$ in serum from Lampetra appendix after 117 days in five treatments.

\begin{tabular}{|c|c|c|c|c|c|c|c|c|}
\hline \multirow[b]{3}{*}{ Treatment } & \multicolumn{4}{|l|}{ Larval } & \multicolumn{4}{|c|}{ Metamorphosing } \\
\hline & \multicolumn{2}{|l|}{$\left[\mathrm{T}_{4}\right]$} & \multicolumn{2}{|l|}{$\left[\mathrm{T}_{3}\right]$} & \multicolumn{2}{|l|}{$\left[\mathrm{T}_{4}\right]$} & \multicolumn{2}{|l|}{$\left[\mathrm{T}_{3}\right]$} \\
\hline & Mean $\pm \mathrm{SE}$ & $N$ & Mean \pm SE & $N$ & Mean $\pm \mathrm{SE}$ & $N$ & Mean $\pm \mathrm{SE}$ & $N$ \\
\hline Control & $32.82 \pm 3.52 a$ & 27 & $28.48 \pm 5.18 d$ & 30 & & & & \\
\hline $\mathrm{NaOH}$ & $28.45 \pm 2.77 a$ & 29 & $26.60 \pm 3.92 d$ & 30 & & & & \\
\hline \multicolumn{9}{|l|}{$\mathrm{KClO}_{4}$} \\
\hline $0.01 \%$ & $10.24 \pm 1.03 b$ & 9 & $2.05 \pm 0.23 e$ & 13 & $9.24 \pm 0.34 c$ & 12 & $1.33 \pm 0.08 h$ & 16 \\
\hline $0.05 \%$ & $11.85 \pm 0.61 b$ & 7 & $1.44 \pm 0.04 f$ & 8 & $8.01 \pm 0.66 c$ & 18 & $1.18 \pm 0.07 i$ & 18 \\
\hline PTU & $15.00 \pm 0.81 b$ & 23 & $5.80 \pm 0.91 g$ & 27 & 9.48 & 1 & 0.94 & 1 \\
\hline
\end{tabular}

Note: Treatment sample sizes $(N)$ differ because of pooling to obtain sufficient serum for RIAs. Mean [T $\left.\mathrm{T}_{4}\right]$ values followed by a common letter are not significantly different at $P \leq 0.05$. Mean $\left[\mathrm{T}_{3}\right]$ values followed by a common letter are not significantly different at $P \leq 0.05$ for either treatment or stage of development.

(Bird and Potter 1979a; Youson and Potter 1979; this study). Thus, the staging criteria for stages 1 through 7 first proposed by Youson and Potter (1979) for lamprey metamorphosis appear to be applicable to both parasitic and nonparasitic species.

The consistency in the patterns of change shown by our measurements of certain body regions (Figs. 3A-3E), particularly the eye, the prebranchial region, and both dorsal fins, provides some validity for the criteria used to separate the metamorphosing animals into the different stages, despite the fact that they represent proportional values from only 1 or 2 specimens per stage. We note that the pattern of change for many measurements is similar to that reported in a study of L. planeri (Bird and Potter 1979b), which used larger sample sizes at each stage than were used in the present investigation. Our data show that the oral disc and prebranchial region undergo rapid increases in relative length in the latter stages of metamorphosis compared with the eye and dorsal fins, which, in L. appendix, increase steadily in size throughout metamorphosis. Trunk depth increases between stage 7 and the adult, presumably reflecting sexual maturation in the animal. In contrast, the functional significance, if any, of the decrease in cloacal and tail lengths is not clear.

Nonparasitic lamprey species tend to metamorphose at a greater age than parasitic species, following an extended larval period (Hardisty and Potter 1971). Statolith aging of individuals demonstrated that $L$. appendix from the Great Lakes tend to metamorphose when they are longer and at least 1 year older than sea lampreys from the same region (Beamish and Medland 1988). We found that L. appendix larvae must be at least $155 \mathrm{~mm}$ (length) and $5.40 \mathrm{~g}$ (mass) in size to initiate spontaneous metamorphosis. This size is greater than the minimum for premetamorphic sea lamprey larvae from the Great Lakes ( $\geq 120 \mathrm{~mm}$ (length) and $\geq 3.0 \mathrm{~g}$ (mass); Youson et al. 1993), premetamorphic L. fluviatilis and L. planeri (Bird and Potter 1979b), and premetamorphic G. australis (Potter et al. 1980). If, as in sea lampreys, lipid is the primary source of energy during the nontrophic phase of metamorphosis (Lowe et al. 1973; Kao et al. 1997), then the large size of premetamorphic L. appendix larvae may reflect a requirement for larger energy reserves to sustain individuals during the nontrophic periods of metamorphosis and subsequent sexual maturation. However, it is not clear why L. appendix is so much larger (length and mass) than some other nonparasitic species (e.g., L. planeri) before, during, and after metamorphosis.

We began the present study in September, when spontaneous metamorphosis of L. appendix is nearly complete, and finished the following January, 6 months prior to the normal initiation of spontaneous metamorphosis, and found that treatment with $\mathrm{KClO}_{4}$ during this period resulted in changes in external morphological features consistent with metamorphosis. The fact that these changes occurred when spontaneous metamorphosis is not normally initiated, and that none of the untreated control animals exhibited similar changes, point to $\mathrm{KClO}_{4}$ as the causative (inducing) agent. This $\mathrm{KClO}_{4}$-induced metamorphosis is consistent with other studies on $\mathrm{KClO}_{4}$ induction both in nonparasitic lampreys, such as L. planeri (Hoheisel and Sterba 1963) and L. reissneri (Suzuki 1986), and in the parasitic lamprey $P$. marinus (Holmes and Youson 1993). Among larvae of comparable size $(\geq 130 \mathrm{~mm})$, exposure to $\mathrm{KClO}_{4}$ induced metamophosis in $98 \%$ of sea lampreys (Holmes and Youson 1993) but in only $62 \%$ of L. appendix (present study), although the concentration of $\mathrm{KClO}_{4}(0.01$ and $0.05 \%)$ did not significantly influence the incidence of metamorphosis in either L. appendix (Fig. 4) or sea lampreys (Holmes and Youson 1993). This difference in the incidence of metamorphosis may be related to fundamental differences in the minimum size required for spontaneous metamorphosis in the two species (e.g., see Fig. 6; Manzon and Youson 1997; Manzon et al. 1998).

Attempts to induce metamorphosis in lampreys using exogenous treatments of PTU have not produced the clear results obtained using $\mathrm{KClO}_{4}$, despite the use of the same concentration of PTU in all studies (10 mg/L). Suzuki (1989) reported complete metamorphosis in some $L$. reissneri individuals treated with PTU for approximately 50 days, but this finding was not replicated in L. appendix (this study) or G. australis (Leatherland et al. 1990). The absence of metamorphosis in these latter studies may not be related to the length of treatment, since we used an exposure period for $L$. appendix (117 days) that was $67 \%$ longer than the 70 days used by Leatherland et al. (1990) and 134\% longer than the period used by Suzuki (1989), however, we were still unable to find clear evidence of metamorphosis in all but one L. appendix. Furthermore, about one-third of the larvae assigned to the PTU treatment in the present study met the minimum size requirements of presumptive metamor- 
phosis, length $155 \mathrm{~mm}$ and mass $5.40 \mathrm{~g}$, so the absence of induced metamorphosis is probably not related to the size or physiological preparation of the animals.

Because metamorphosing L. appendix were significantly larger than nonmetamorphosing larvae exposed to the goitrogens or larvae in the control treatments, we hypothesize that the variable response to $\mathrm{KClO}_{4}$ among animals of different size is related to differences in metabolic condition, particularly with respect to lipid metabolism. Kao et al. (1997) found that spontaneous metamorphosis in sea lampreys was dominated by lipogenesis up to stage 3 , and that the later stages were characterized by enhanced lipolysis and reduced lipogenesis and oxidative metabolism, relative to nonmetamorphosing larvae. If similar mechanisms are present in L. appendix, then metamorphosing animals may be better able than nonmetamorphosing larvae to cope with the energetic demands of metamorphosis and the higher than normal temperatures used in the present study. However, we did not design our study to examine the effects of goitrogens on size, so a definitive conclusion awaits further investigation.

Our interpretation of the serum TH data (Fig. 4) is cautious, because serum samples were collected from stage 1 animals 1 year prior to collecting them from animals in other stages of metamorphosis. Nevertheless, we are confident that our findings that serum levels of both $\mathrm{T}_{4}$ and $\mathrm{T}_{3}$ decline by stage 2 and remain low during the subsequent stages of metamorphosis are real, because this pattern is generally similar to the changes in $\mathrm{T}_{4}$ and $\mathrm{T}_{3}$ serum levels observed during spontaneous metamorphosis of sea lampreys (Wright and Youson 1977; Lintlop and Youson 1983; Youson et al. 1994). However, we are unable to explain why serum concentrations of $\mathrm{T}_{4}$ peak in stage 1 animals rather than in premetamorphic larvae. Concentrations of $T_{3}$ for these same animals were significantly depressed compared with those in premetamorphic larvae, a situation consistent with that observed in sea lampreys. We are certain that our L. appendix data are not an artifact of the RIA procedure, since several early analyses of the same serum samples using differing dilutions produced similar results. We are also confident that incorrect staging is not a factor, because the stage 1 animals were sampled at a time of year well after spontaneous metamorphosis has begun (18 July 1995), and the range of their lengths overlapped that of premetamorphic larvae. Although the sample size for stage 1 is small $(N=5)$, the $\mathrm{T}_{4}$ data are consistently high for all animals in the sample, so we believe individual variation is minimal. If this finding is subsequently confirmed using data from animals sampled at consecutive stages during a single metamorphic period, then it could have considerable impact on our understanding of the role of $\mathrm{TH}$ in the metamorphosis of this lamprey species.

Lampreys exposed to the goitrogens $\mathrm{KClO}_{4}$ and PTU have significantly lower serum TH levels than untreated control animals (Suzuki 1986; Youson et al. 1995; Manzon and Youson 1997), but only exposure to $\mathrm{KClO}_{4}$ consistently induces metamorphosis in all lamprey species tested (Hoheisel and Sterba 1963; Suzuki 1986; Holmes and Youson 1993; present study). Although the reductions in serum TH values in animals exposed to either goitrogen (Youson et al. 1995; Table 1) are proportionately similar to those observed during spontaneous metamorphosis, a decline in serum $\mathrm{TH}$ levels by itself does not trigger metamorphosis in lampreys. Thus, the hypothesis that these goitrogens act on the endostyle (larval precursor to the follicular thyroid gland in juveniles and adults) to suppress production of the TH (Youson 1997) triggering metamorphosis does not fully explain our findings, particularly those for PTU. The induction of metamorphosis, particularly with $\mathrm{KClO}_{4}$, probably involves other unknown effects either on the putative thyroid gland itself, on other tissues outside the thyroid axis, on the peripheral metabolism of the $\mathrm{TH}$, or on general body metabolism. There is no available evidence of hypothalamic-pituitary control involving TH during spontaneous metamorphosis in lampreys, nor have $\mathrm{TH}$ receptors in $\mathrm{TH}$-targeted tissues been identified in lampreys (Youson 1997). However, morphological studies have shown that gut degeneration in the nonparasitic L. planeri begins around the time when the rate of gonadal development increases, and may be at least partially related to the secretion of gonadal hormones (Hilliard et al. 1983). In amphibians such as the bullfrog Rana catesbeiana, some of the events in metamorphosis are regulated by the expression of type I and type III deiodinase genes in specific tadpole tissues (Becker et al. 1997). Although Eales et al. (1997) suggested that monodeiodinase pathways might have an important role in lamprey metamorphosis, recent data indicate that $\mathrm{KClO}_{4}$ does not affect the $\mathrm{T}_{4}$ outer ring deiodination pathway to $\mathrm{T}_{3}$ in sea lampreys (Manzon et al. 1998). Kao et al. (1997) noted that a switch in lipid metabolism from lipogenesis to lipolysis, which occurs at stage 3 , is a key event in sea lamprey metamorphosis. We suggest that $\mathrm{KClO}_{4}$ may act directly on this pathway to induce metamorphosis in lampreys.

In summary, the sequence of stages in the metamorphosis of L. appendix is similar to that given for Lampetra spp. (Bird and Potter 1979a), P. marinus (Youson and Potter 1979), and G. australis (Potter et al. 1980). The most diagnostic changes in the early stages are the enlargement of the eye and the differentiation into iris and pupil, followed by the modification of the oral hood into an oral disc and changes in body pigmentation. The changes in the relative lengths of various body regions are consistent with the more extensive data reported for L. planeri (another nonparasitic species). Premetamorphic and metamorphosing larvae of L. appendix are much larger (minimum length, $155 \mathrm{~mm}$; minimum mass, $5.40 \mathrm{~g}$ ) than those of most parasitic or nonparasitic species of lamprey. Average serum TH levels increase during the latter part of larval life and decline approximately $90 \%$ by stage 2 of metamorphosis, remaining at the reduced levels throughout the later stages. We are not certain of serum $\mathrm{TH}$ levels at stage 1 of metamorphosis, because our data for this stage are from animals collected 1 year earlier than those in all other stages.

Exposure to $\mathrm{KClO}_{4}$ appears to induce metamorphosis in larvae of $L$. appendix more readily than exposure to PTU (62 and 3\%, for $\mathrm{KClO}_{4}$ and PTU, respectively), and also results in larger declines in serum $\mathrm{TH}$ levels. These findings with $\mathrm{KClO}_{4}$ are consistent with those reported for sea lampreys (Holmes and Youson 1993; Youson et al. 1995). The highest concentration of $\mathrm{KClO}_{4}$ used in the present study seemed to overcome the size and CF criteria that may be important in spontaneous metamorphosis of L. appendix. Lamprey metamorphosis, either spontaneous or induced, is accompanied by a significant decrease in serum TH levels, but other 
regulatory pathways are likely involved in this process, since a decline in serum TH levels caused by exposure to a goitrogen is not sufficient by itself to initiate metamorphosis.

\section{Acknowledgments}

This study was supported primarily by a contract from the Great Lakes Fishery Commission to J.H.Y., J.A.H., and F.W. Keeley. Funds from the Natural Sciences and Engineering Research Council of Canada (NSERC) to J.H.Y. and NSERC postgraduate fellowship to R.G.M. are acknowledged. We thank Quoc Huynh for doing the $T_{3}$ RIAs on sera from the induction experiment.

\section{References}

Beamish, F.W.H., and Medland, T.E. 1988. Age determination for lampreys. Trans. Am. Fish. Soc. 117: 63-71.

Becker, K.B., Stephens, K.C., Davey, J.C., Schneider, M.J., and Galton, V.A. 1997. The type 2 and type 3 iodothyronine deiodinases play important roles in coordinating development in Rana catesbeiana tadpoles. Endocrinol. 138: 2989-2997.

Bird, D.J., and Potter, I.C. 1979a. Metamorphosis in the paired species of lampreys, Lampetra fluviatilis (L.) and Lampetra planeri (Bloch). 1. A description of the timing and stages. J. Linn. Soc. Lond. Zool. 65: 127-143.

Bird, D.J., and Potter, I.C. 1979b. Metamorphosis in the paired species of lampreys, Lampetra fluviatilis (L.) and Lampetra planeri (Bloch). 2. Quantitative data for body proportions, weights, lengths and sex ratios. J. Linn. Soc. Lond. Zool. 65: $145-160$.

Cole, W.C., and Youson, J.H. 1981. The effect of pinealectomy, continuous light, and continuous darkness on metamorphosis of anadromous sea lampreys, Petromyzon marinus L. J. Exp. Zool. 218: 397-404.

Eales, J.G., Holmes, J.A., McLeese, J.M., and Youson, J.H. 1997. Thyroid hormone deiodination in various tissues of larval and upstream-migrant sea lampreys, Petromyzon marinus. Gen. Comp. Endocrinol. 106: 202-210.

Galton, V.A. 1988. The role of thyroid hormone in amphibian development. Am. Zool. 28: 309-318.

Galton, V.A., Davey, J.C., and Schneider, M.J. 1994. Mechanisms of thyroid hormone action in developing Rana catesbeiana tadpoles. In Perspectives in comparative endocrinology: Invited papers from XII International Congress of Comparative Endocrinology, Toronto, Ont., 16-21 May 1993. Edited by K.G. Davey, R.E. Peter, and S.S. Tobe. National Research Council of Canada, Ottawa. pp. 412-415.

Hardisty, M.W., and Potter, I.C. 1971. Paired species. In The biology of lampreys. Vol. 1. Edited by M.W. Hardisty and I.C. Potter. Academic Press, London. pp. 249-277.

Hilliard, R.W., Bird, D.J., and Potter, I.C. 1983. Metamorphic changes in the intestine of three species of lampreys. J. Morphol. 176: $181-196$.

Hoheisel, G., and Sterba, G. 1963. Über die Wirkung von Kaliumperchlorat $\left(\mathrm{KClO}_{4}\right)$ auf Ammocoetes von Lampetra planeri Bloch. Z. Mikrosk. Anat. Forsch. (Leipz.), 70: 490-516.

Holmes, J.A., and Youson, J.H. 1993. Induction of metamorphosis in landlocked sea lampreys, Petromyzon marinus. J. Exp. Zool. 267: 598-604.

Holmes, J.A., and Youson, J.H. 1997. Laboratory study of the effects of spring warming and larval density on the metamorphosis of sea lampreys. Trans. Am. Fish. Soc. 126: 647-657.
Holmes, J.A., Beamish, F.W.H., Seelye, J.G., Sower, S.A., and Youson, J.H. 1994. Long-term influence of water temperature, photoperiod, and food deprivation on metamorphosis of sea lamprey, Petromyzon marinus. Can. J. Fish. Aquat. Sci. 51: 2045-2051.

Inui, Y., and Miwa, S. 1985. Thyroid hormone induces metamorphosis in flounder larvae. Gen. Comp. Endocrinol. 60: 450-454.

Inui, Y., Miwa, S., Yamano, K., and Hirano, T. 1994. Hormonal control of flounder metamorphosis. In Perspectives in comparative endocrinology: Invited papers from XII International Congress of Comparative Endocrinology, Toronto, Ont., 16-21 May 1993. Edited by K.G. Davey, R.E. Peter, and S.S. Tobe. National Research Council of Canada, Ottawa. pp. 408-411.

Kao, Y.-H., Youson, J.H., Holmes, J.A., and Sheridan, M.A. 1997. Changes in lipolysis and lipogenesis in selected tissues of the landlocked lamprey, Petromyzon marinus, during metamorphosis. J. Exp. Zool. 277: 301-312.

Leatherland, J.F., Hilliard, R.W., MacKay, D.J., and Potter, I.C. 1990. Changes in serum thyroxine and triiodothyronine concentrations during metamorphosis of the southern hemisphere lamprey, Geotria australis, and the effect of propylthiouracil, triiodothyronine, and environmental temperature on serum thyroid hormone concentration of ammocoetes. Fish Physiol. Biochem. 8: $167-177$.

Lintlop, S.P., and Youson, J.H. 1983. Concentration of triiodothyronine in the sera of the sea lamprey, Petromyzon marinus, and the brook lamprey, Lampetra lamottenii, at various phases of the life cycle. Gen. Comp. Endocrinol. 49: 187-194.

Lowe, D.R., Beamish, F.W.H., and Potter, I.C. 1973. Changes in the proximate body composition of Petromyzon marinus (L.) during larval life and metamorphosis. J. Fish Biol. 5: 673-682.

Manzon, R.G., and Youson, J.H. 1997. The effects of exogenous thyroxine $\left(\mathrm{T}_{4}\right)$ or triiodothyronine $\left(\mathrm{T}_{3}\right)$, in the presence and absence of potassium perchlorate, on the incidence of metamorphosis and on serum $\mathrm{T}_{4}$ and $\mathrm{T}_{3}$ concentrations in larval sea lampreys (Petromyzon marinus L.). Gen. Comp. Endocrinol. 106: $211-220$.

Manzon, R.G., Eales, J.G., and Youson, J.H. 1998. Blocking of $\mathrm{KClO}_{4}$-induced metamorphosis in premetamorphic sea lampreys by exogenous thyroid hormones $(\mathrm{TH})$; effects of $\mathrm{KClO}_{4}$ and $\mathrm{TH}$ on serum TH concentrations and intestinal thyroxine outer-ring deiodination. Gen. Comp. Endocrinol. 112: 54-62.

Meyer-Rochow, Y.B., and Stewart, D. 1996. Review of larval and postlarval eye ultrastructure in the lamprey (Cyclostomata) with special emphasis on Geotria australis (Gray). Microsc. Res. Tech. 35: 431-444.

Miwa, S., and Inui, Y. 1987. Effects of various doses of thyroxine and triiodothyronine on the metamorphosis of flounder (Paralichthys olivaceus). Gen. Comp. Endocrinol. 67: 356-363.

O'Boyle, R.N., and Beamish, F.W.H. 1977. Growth and intermediary metabolism of larval and metamorphosing stages of the landlocked sea lamprey, Petromyzon marinus L. Environ. Biol. Fishes, 2: 103-120.

Potter, I.C. 1980. The ecology of larval and metamorphosing lampreys. Can. J. Fish. Aquat. Sci. 37: 1641-1657.

Potter, I.C., Wright, G.M., and Youson, J.H. 1978. Metamorphosis in the anadromous sea lamprey, Petromyzon marinus L. Can. J. Zool. 56: 561-570.

Potter, I.C., Hilliard, R.W., and Bird, D.J. 1980. Metamorphosis in the southern hemisphere lamprey, Geotria australis. J. Zool. (Lond.), 190: 405-430.

Sagnes, P. 1997. Potential artefacts in morphometric analyses of fish: effects of formalin preservation on $0+$ grayling. J. Fish. Biol. 50: 910-914. 
Suzuki, S. 1986. Induction of metamorphosis and thyroid function in the larval lamprey. In Frontiers in thyroidology. Vol. 1. Edited by G. Mederios-Neto and E. Gaitan. Plenum Press, New York. pp. 667-670.

Suzuki, S. 1989. Why are goitrogens chemical triggers of metamorphosis in the lamprey? Relationship between thyroid function and metamorphosis. Gen. Comp. Endocrinol. 74: 277.

Wright, G.M., and Youson, J.H. 1977. Serum thyroxine concentrations in larval and metamorphosing anadromous sea lamprey, Petromyzon marinus L. J. Exp. Zool. 202: 27-32.

Youson, J.H. 1988. First metamorphosis. In Fish physiology. Vol. XIB. Edited by W.S. Hoar and D.J. Randall. Academic Press, New York. pp. 135-196.

Youson, J.H. 1997. Is lamprey metamorphosis regulated by thyroid hormones? Am. Zool. 37: 439-458.

Youson, J.H., and Potter, I.C. 1979. A description of the stages in the metamorphosis of the anadromous sea lamprey, Petromyzon marinus L. Can. J. Zool. 57: 1808-1817.
Youson, J.H., Lee, J., and Potter, I.C. 1979. The distribution of fat in larval, metamorphosing, and adult anadromous sea lampreys, Petromyzon marinus L. Can. J. Zool. 57: 237-246.

Youson, J.H., Holmes, J.A., Guchardi, J.A., Seelye, J.G., Beaver, R.E., Gersmehl, J.E., Sower, S.A., and Beamish, F.W.H. 1993. Importance of condition factor and the influence of water temperature and photoperiod on metamorphosis of sea lamprey, Petromyzon marinus. Can. J. Fish. Aquat. Sci. 50: 2448-2456.

Youson, J.H. Plisetskaya, E.M., and Leatherland, J.F. 1994. Concentrations of insulin and thyroid hormones in the serum of landlocked sea lampreys (Petromyzon marinus) of three larval year classes, larvae exposed to two temperature regimes, and both during and after metamorphosis. Gen. Comp. Endocrinol. 94: 294-304.

Youson, J.H., Holmes, J.A., and Leatherland, J.F. 1995. Serum concentrations of thyroid hormones in $\mathrm{KClO}_{4}$-treated larval sea lampreys (Petromyzon marinus L.). Comp. Biochem. Physiol. C Pharmacol. Toxicol. Endocrinol. 111: 265-270. 